\title{
I S Monetary Policy Necessary for the Economic Development of Less Developed Countries with Special Reference to Pakistan
}

\section{Rabia Najaf*}

Riphah International University Islamabad, Islamic Business and Finance, Pakistan

\begin{abstract}
In this paper, observed that impact of monetary policy on development of under developing country like Pakistan. For this purpose, we have utilized the OLS model and taken data from 1982 to 2009. Our results are showing that there is negative association between monetary policy and inflation and there is positive association with GDP and Bop. The most effected recommendations are that for better growth there is need of best favorable investment climate for appropriate interest rate, liquidity management and money market.
\end{abstract}

Keywords: OLS Model; Interest rate; Exchange rate; BOP; Money market; Liquidity management

\section{Introduction}

Monetary policy is way that tells us that how can be maintained economic growth. It has influenced on economic growth, price stability and BOP. According to act 1958, central bank made polices of monetary policy. In simple words, and monetary policy is such a process, in which central bank and monetary authority of that country control supply of money. Since 1970, Fiscal policy has generally been formed after monetary policy. Most of studies had been proved monetary policy as contractionary. Expansionary monetary policy diminishes the worth of currency (Figure 1). Mostly, monetary policy is generally associated with availability of credit. Monetary policy has main tools are short term interest rate and another main tool is bank reserves. In many countries, there are two types of monetary policy 1) decisions about coinage 2) decisions to print money. Central banking system was set up in 1890 and after this point central bank is known as last resort.

Every year state bank of Pakistan makes its monetary policy and rules and makes unchanged policy rate. In August CPI rate was 5.75\%. After deliberations the committee of SBP has maintained its policy rate at $5.78 \%$. For the proper, decision there held a meeting in Washington and finance minister Shaq Dar were highlight issues our banking system now a days and he also address the major issues, which are facing Pakistani s' nation now a days.

Monetary policy has main role in the development of economy; with the help of monetary policy Government can control inflation

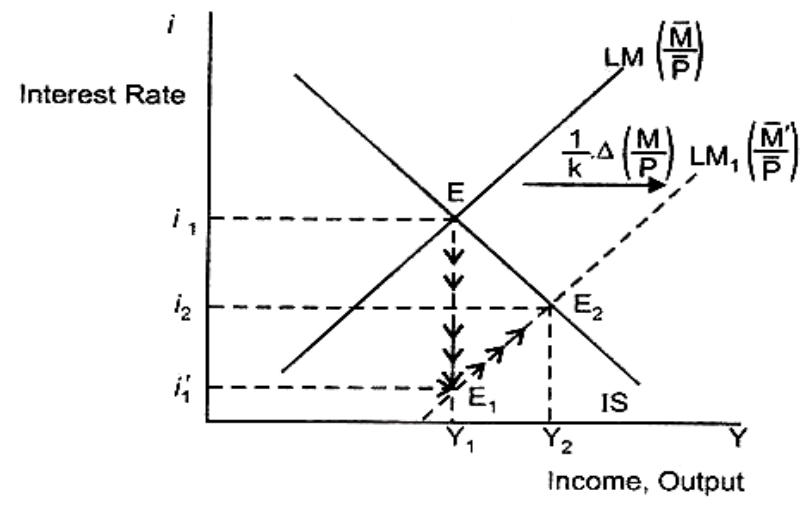

Figure 1: Expansionary monetary policy. and can maintain BOP. The principle objective of monetary policy is to control money. Monetary policy has role to promote economic development and stabilize exchange rate. Monetary policy is acting a main role to control inflationary pressures. Mostly, monetary policy used quantitative and qualitative methods for measuring inflation rate. Open markets are small, therefore, monetary policy is not applied properly.

\section{To Achieve Price Stability}

Monetary policy acts as bridge between supplies and demand therefore; it is seen as the best way to achieve price stability. Monetary authorities are taking a better decision for further improvement of poverty of all under developed countries. Monetary policy in the shape of interest rate and interest rate plays an important role for enhancement of poverty level. Government can be completed their planning with help of monetary policy. For instance, they have authority to develop their country to establish infrastructure, transport, chemicals etc. Monetary authority is being focused on interest rate policy because interest rate policy is known as anti-inflationary.

\section{Objective}

1. Impact of monetary supply on GDP of Pakistan.

2. Impact of monetary policy on BOP.

3. Impact of monetary policy on inflation.

\section{Problem Statement}

Is monetary policy in importance for development of less developed country?

\section{Literature Review}

The following authors found there is positive association between

*Corresponding author: Rabia Najaf, Riphah International University Islamabad, Pakistan, Islamic Business and Finance, Pakistan, Tel: +92 51111510 510; E-mail: rabianaajf@gmail.com

Received February 25, 2017; Accepted March 09, 2017; Published March 16 , 2017

Citation: Najaf R (2017) I S Monetary Policy Necessary for the Economic Development of Less Developed Countries with Special Reference to Pakistan Bus Eco J 8: 289. doi: 10.4172/2151-6219.1000289

Copyright: () 2017 Najaf R. This is an open-access article distributed under the terms of the Creative Commons Attribution License, which permits unrestricted use, distribution, and reproduction in any medium, provided the original author and source are credited. 
Citation: Najaf R (2017) I S Monetary Policy Necessary for the Economic Development of Less Developed Countries with Special Reference to Pakistan. Bus Eco J 8: 289. doi: 10.4172/2151-6219.1000289

monetary policy and GDP. Monetary authority had suggested that Government should have focused on inflation rate.

Adefeso and Mobolaji [1] analyzed impact of monetary policy on development of India, for proper results they had taken data from 1998 to 2008 and applied OLS model.

Borio [2] analyzed impact of monetary policy on development of Pakistan, for proper results they had taken data from 1991 to 2010 and applied VAR model.

Diamond [3] viewed impact of monetary policy on development of USA, for proper results they had taken data from 1995 to 2005 and applied VECM model.

Folawewo and Osinubi [4] examined impact of monetary policy on development of UK, for proper results they had taken data from 1991 to 2001 and applied VECM model.

Friedman [5], observed impact of monetary policy on development of Asian countries, for proper results they had taken data from 1999 to 2009 and applied unit root and ADF model.

Friedman and Schwartz [5], viewed impact of monetary policy on development of Malaysia, for proper results they had taken data from 1994 to 2004 and applied ECM model.

Gertler and Gilchrist [6], analyzed impact of monetary policy on development of France, for proper results they had taken data from 1991 to 2001 and applied VECM model.

Keynes [7] viewed impact of monetary policy on development of Russia, for proper results they had taken data from 1999 to 2012 and applied OLS model.

Kogar [8], examined impact of monetary policy on development of Libya, for proper results they had taken data from 1996 to 2008 and applied multi regression model.

Modigliani [9] observed impact of monetary policy on development of Japan, for proper results they had taken data from 1991 to 2001 and applied VECM model.

\section{Methodology}

The purpose of this research is to find out impact of monetary policy on the money supply, GDP and economy of Pakistan [10]. For this purpose, taken data from 1982 to 2009 and applied OLS model, here monetary policy is dependent variable and GDP, inflation and $\mathrm{BOP}$ are independent variables.

\section{Equations}

\section{Model 1}

$\operatorname{gdp}=\mathrm{a}_{0}+\mathrm{a}_{1} \operatorname{lr}+\mathrm{a}_{2} \mathrm{M}_{2}+\mathrm{a}_{3} \mathrm{Cr}+\mathrm{U}_{\mathrm{i}}$

Where

gdp: Gross Domestic Product

Lr: Liquidity ratio

$\mathrm{M}_{2}$ : Broad Money Supply

Cr: Cash ratio

$\mathrm{a}_{0}, \mathrm{a}_{1}, \mathrm{a}_{2}$ and $\mathrm{a}_{3}:$ Parameters

Ui: Error term

\section{Model II}

inf $=\mathrm{b}_{0}+\mathrm{b}_{1} \mathrm{lr}+\mathrm{b}_{2} \mathrm{M}_{2}+\mathrm{b}_{3} \mathrm{Cr}+\mathrm{U}_{\mathrm{i}}$

Where

inf: Inflation rate

Lr: Liquidity ratio

$\mathrm{M}_{2}$ : Broad Money Supply

Cr: Cash ratio

$\mathrm{b}_{0}, \mathrm{~b}_{1}, \mathrm{~b}_{2}$ and $\mathrm{b}_{3}:$ Parameters

Ui: Error term

\section{Model III}

bop $=\mathrm{c}_{0}+\mathrm{c}_{1} \operatorname{lr}+\mathrm{c}_{2} \mathrm{M}_{2}+\mathrm{c}_{3} \mathrm{Cr}+\mathrm{U}_{\mathrm{i}}$

Where

bop: Balance of payment

Lr: Liquidity ratio

$\mathrm{M}_{2}$ : Broad Money Supply

Cr: Cash ratio

$\mathrm{c}_{0}, \mathrm{c}_{1}, \mathrm{c}_{2}$ and $\mathrm{c}_{3}$ : Parameters

Ui: Error term

Sample: 19812007

Included observations: 28

Test assumption: Linear deterministic trend in the data

Series: GDP INFLR BOP LQR CASHR MS Lags interval: 1 to 1

\section{Model estimation}

$\mathrm{BOP}=-102969.7+2257.86(\mathrm{LQR})+0.652737\left(\mathrm{MS}_{2}\right)-15777.86$ (CASHR)

$\mathrm{T}=(-0.162)(0.166347)(7.271161)(-0.417154)$

\section{Empirical Results}

In this paper, we analyzed impact of monetary policy on GDP of Pakistan, for this purpose, we utilized unit root, Johansen cointegration, regression and VECM model. We conducted unit root test for checking stationary between macroeconomic variables [11-13]. Unit root also determine level of co-integration between variables. In Table 1 there are found stationary between variables. Table 1 is showing that null hypothesis is rejected. This thing is prompt us to apply ADF test. These are showing that some variables are stationary at level first I while some are at order 2 . Table 2 is showing that not any variable is stationary at levels. The observed values of ADF are showing level of stationary. The results are providing some evidences that variables are non-stationary here, after taking results null hypothesis is accepted. The results are showing that some variables are stationary at level 1

\begin{tabular}{|l|l|l|l|l|}
\hline & 5 Percent & 1 Percent & Hypothesized & \\
\hline Eigenvalue & Ratio & Critical value & No. of CE(s) & \\
\hline 0.935595 & 213.3559 & 94.16 & 103.19 & None \\
\hline 0.89945 & 144.7922 & 68.53 & 76.08 & At most 1 \\
\hline 0.836303 & 87.36714 & 47.22 & At most 2 \\
\hline \multicolumn{5}{|c|}{ Table 1: Co-Integration Test. } \\
\end{tabular}


Citation: Najaf R (2017) I S Monetary Policy Necessary for the Economic Development of Less Developed Countries with Special Reference to Pakistan. Bus Eco J 8: 289. doi: 10.4172/2151-6219.1000289

while; some are stationary at level 2. After applying unit root test and applied co integration between the variables. After co-integration, it is found that there is long run equilibrium (Tables 3 and 4). There is cointegration between monetary policy and macroeconomic variables. In this paper, there are found mathematical relationship between these variables. Our regression results are showing that there is linear relationship between GDP and explanatory variables. The values of $\mathrm{R}^{2}$ is showing endogenous variables jointly explained. The value adjusted $\mathrm{R}^{2}$ is showing that model is significant and values of Durbin Watson is showing positive autocorrelation between variables [14-16]. The values of F-statistics are showing statistically satisfactory results. All these results are showing that there is significant impact of monetary policy on GDP of Pakistan. The empirical results are showing that there is direct association between monetary policy and all other variables. Our results are also trying to show that there is negative relationship between monetary policy and inflation. Our results are showing that there is indirect relationship between inflation and macroeconomic variables. Our final results are showing that money supply is also related with balance of payment. Tight monetary policy has bad impact on GDP on economy.

\section{Summary}

1. This paper is trying to expose that central bank of Pakistan has crucial role for development of economy.

2. The results of regression are showing that central bank of Pakistan has not linkage with the increasing inflation rate.

\begin{tabular}{|c|c|c|c|c|}
\hline Variable & Coefficient & Std. Error & t-Statistic & Prob. \\
\hline C & -105615.7 & 1116195 & -0.094622 & 0.9255 \\
\hline LQR & 471.2587 & 23756.77 & 0.019838 & 0.9844 \\
\hline CASHR & 38075.84 & 66199.75 & 0.575167 & 0.5709 \\
\hline $\mathrm{MS}_{2}$ & 4.295953 & 0.157123 & 27.34148 & 0 \\
\hline \multicolumn{5}{|c|}{$\begin{array}{l}\text { Source; Author's estimation using E-view } 3.0 \\
R^{2}=0.9717398 \\
F(3,28)=263.6124 \\
\text { Adj. } R^{2}=0.9680534 \\
D W=1.382417\end{array}$} \\
\hline
\end{tabular}

Table 2: Co-Integration Test Coefficient 0.9717398.

\begin{tabular}{|c|c|c|c|c|}
\hline Variable & Coefficient & Std. Error & t-Statistic & Prob. \\
\hline C & 5388054 & 18.24944 & 2.95246 & 0.0072 \\
\hline LQR & -0.561755 & 0.388417 & -1.44628 & 0.1617 \\
\hline CASHR & -0.0000299 & 0.0000258 & -1.159594 & 0.2582 \\
\hline $\mathrm{MS}_{2}$ & 0.357664 & 1.082346 & -0.330452 & 0.7442 \\
\hline \multicolumn{5}{|c|}{$\begin{array}{l}\text { Source; Author's estimation using E-view } 3.0 \\
R^{2}=0.17623 \\
F,(3,28)=1.6460245 \\
D W=1.028959 \\
\text { Adj. } R^{2}=0.068771\end{array}$} \\
\hline
\end{tabular}

Table 3: Co-Integration Test Coefficient 0.17623.

\begin{tabular}{|l|l|l|l|l|}
\hline Variable & Coefficient & Std. Error & t-Statistic & Prob. \\
\hline C & -102969.7 & 637728.9 & -0.161464 & 0.874 \\
\hline LQR & 2257.853 & 13573.26 & 0.166347 & 0.8694 \\
\hline MS $_{2}$ & 0.652737 & 0.089772 & 7.27117 & 0 \\
\hline CASHR & -15777.86 & 37822.73 & -0.417154 & 0.6805 \\
\hline $\begin{array}{l}\text { Source; Author's estimation using E-view 3.0 } \\
R^{2}=0.707681 \\
\text { F, }(3,27)=18.56037 \\
\text { DW }=1.533354 \\
\text { Adj. } R^{2}=0.669552\end{array}$ & \\
\end{tabular}

Table 4: Co-Integration Test Coefficient 0.707681.
3. This paper is also trying to show that central bank monetary policies have best impact on GDP of Pakistan.

4. Inflation can be improved by providing different policies like employment, improving operations of financial markets.

\section{Conclusion}

From last few decades, the central bank of Pakistan has crucial role in development of economy. The central bank of Pakistan used latest techniques for better monetary policy management and with help of indirect control system central bank runs open market operations.

\section{References}

1. Adefeso $\mathrm{H}$, Mobolaji $\mathrm{H}$ (2010) The fiscal-monetary policy and economic growth in Nigeria: further empirical evidence. Pakistan Journal of Social Sciences 7: 142.

2. Borio C (1995) The structure of credit to the non-government sector and the transmission mechanism of monetary policy: A Cross-Country Comparison. Bank for International Settlement Working Paper.

3. Diamond R (2003) Irving Fisher on the international transmission of boom and depression through money standard. Journal of Money, Credit and Banking 35: 49.

4. Folawewo A, Osinubi T (2006) Monetary policy and macroeconomic instability in Nigeria: A Rational Expectation Approach. Journal of Social Science 12: 93-100.

5. Friedman M, Schwartz A (1963) Money and business cycles. Review of Economics and Statistics, pp: 32-64.

6. Gertler M, Gilchrist S (1991) Monetary policy, business cycles and the behaviour of small manufacturing firms. National Bureau of Economic Research. Cambridge.

7. Keynes J (1930) Treatise on money. Macmillian P: 90.

8. Kogar C (1995) Financial innovations and monetary control. The Central Bank of the Republic of Turkey.

9. Modigliani $F$ (1963) The monetary mechanism and its interaction with rea phenomena. Review of Economics and Statistics, pp: 79-107.

10. Batini N (2004) Achieving and maintaining price stability in Nigeria. IMF Working Paper.

11. Busari D, Omoke P, Adesoye B (2002) Monetary policy and macroeconomic stabilization under Alternative exchange rate regime: evidence from Nigeria.

12. Milton $\mathrm{F}$ (1968) The role of monetary policy. American Economic Review 58 : 1-17

13. Nnanna OJ (2001) The monetary policy framework in Africa: The Nigerian experience, pp: 11

14. Oliner S, Rudebusch G (1995) Is there a bank lending channel for monetary policy? Economic Review, pp: 3-20.

15. Sanusi J (2002) Central Bank and the macroeconomic environment in Nigeria.

16. Tobin J (1978) A proposal for international monetary reform. Easter Economic Journal 4: 153-159. 